\title{
IDEOLOGI DALAM IKLAN KELUARGA BERENCANA PERIODE 2004-2014
}

\author{
Yustisia Ditya Sari $^{{ }^{*},}$, Inri Inggrit Indrayani ${ }^{1}$, dan Titi Nur Vidyarini ${ }^{1}$ \\ ${ }^{1}$ Program Studi Ilmu Komunikasi, Fakultas Ilmu Komunikasi, Universitas Kristen Petra \\ Jl. Siwalankerto 121-131, Surabaya \\ * Korespondensi penulis; Email: yustisia@petra.ac.id
}

\begin{abstract}
ABSTRAK
Program Keluarga Berencana (KB) yang diluncurkan oleh pemerintah sejak tahun 1960an merupakan sebuah pendekatan kegiatan komunikasi dan informasi kepada khalayaknya atau masyarakat Indonesia dalam peningkatan kependudukan yang berkualitas. Perencanaan, pengorganisasian, pelaksanaaan dan pengendalian program KB merupakan upaya pengoptimalan keluarga yang sehat baik untuk ibu maupun anak. Upaya ini diwujudkan dalam bentuk pelayanan keluarga berencana melalui program kesehatan baik berupa pemilihan alat kontrasepsi dan pengkomunikasian program melalui media massa seperti cetak ataupun elektronik, misalnya iklan keluarga berencana. Pada tahun 2004 hingga 2014 di masa pemerintahan Susilo Bambang Yudhoyono telah melakukan revitalisasi program kesehatan keluarga berencana berupa praktik-praktik iklan. Praktik ideologi yang terjadi dalam iklan-iklan program KB merupakan bagian dari salah satu kegiatan komunikasi kesehatan melalui media kampanye. Dalam penelitian penulis melakukan penelitian berupa praktek ideologi dalam iklan keluarga berencana periode 2004-2014 sebagai semiotika dalam sebuah studi kualitatif. Hasil penelitian menunjukkan bahwa terdapat keterkaitan media promosi iklan dalam praktek ideologi pemerintah. Di era kepemimpinan SBY, bersifat melanggengkan serta meneruskan saja kebijakan Orde Baru. Keluarga modern kemudian di era SBY digambarkan sebagai keluarga dengan dua anak. Ibu tetap menjalani peran sebagai penguasa domestik yang bertanggung jawab pada pertumbuhan anak
\end{abstract}

Kata kunci: Praktek Ideologi, Iklan, keluarga Berencana (KB), Periode 2004-2014

\begin{abstract}
Family planning $(K B)$ program, which was launched by the government since the 1960s is one of the approach used to improve the population quality of life and the welfare of people in Indonesia. The progra's stages are Planning, organizing, actuating and controlling is a systematic "effort" in optimizing a healthy family, for both the mother and child. That effort was manifested in the form of KB services as one of the health program, through selection of contraception, and disseminate it in the form of promotional advertising, through mass media both printed and electronic. In 2004 to 2014, during the period of Susilo Bambang Yudhoyono (SBY), the program strategic promotion was focus on advertisement, since it was considered capable of explaining the essential of the program and bringing it up as an ideology through the health program and campaign. The researchers were conducting a qualitative semiotic study on the ideology brought up in the commercial. The results showed that there was a linkage between media advertising campaign and the Indonesian government ideology at that period. In the era of SBY's leadership, the main plan and objective were to perpetuate and continuing the policy established since the New Order policies (Orde Baru). A good quality and modern family was described as a family with only two children. Mother still took on the role as the domestic authorities responsible for the growth of their children.
\end{abstract}

Keywords: Ideology, Advertising, family planning (FP), Period 2004-2014.

\section{PENDAhUluaN}

Program Keluarga Berencana mengalami berbagai fase yakni, Program Klinik, dimana program ini dikomunikasikan melalui kesehatan; pendekatan integratif di tahun 1969-1974; di tahun 1979 hingga 1984, program KB dilaksanakan dengan nama Panca Karya dan Catur Bhava Utama dengan strategi mass campaign dengan nama "Safari KB Senyum
Terpadu"; tahun 1984-1988, pendekatan koordinasi aktif pemerintah dan masyarakat diluncurkan, bersamaan dengan kampanye Lingkaran Biru; Kampanye Lingkaran Emas dilaksanakan pada tahun 1988-1993, program ini menekankan variasi alat kontrasepsi dan penetapan UU no 10 tahun 1992 tentang Perkembangan Kependudukan dan Pembangunan Keluarga Sejahtera; pasca reformasi, program $\mathrm{KB}$ dijadikan program Pembangunan 
Nasional, BKKN berubah menjadi Badan Kependudukan dan Keluarga Berencana Nasional, serta visi BKKBN yang baru yakni "Penduduk Tumbuh Seimbang 2015 (profil BKKBN, 2014). Program perencanaan keluarga pada masa orde baru dianggap sebagai program yang berhasil karena terdapat sentralisasi pelaksanaan 'top down' yang sistematis dari koordinasi pusat hingga RW dan RT (Burhani, 2010).

Newland (2001) dalam penelitiannya mengenai program KB di Jawa Barat pada masa orde baru mengungkapkan sistem $\mathrm{KB}$ yang terorganisir dengan nama Keluarga Sejahtera, sistem komunikasi program $\mathrm{KB}$ ini terdiri dari kunjungan mandiri dari tim BKKBN dan kegiatan 'safari' dimana kader BKKBN didampingi $\mathrm{ABRI}$ mendatangi calon pelaku kontrasepsi; program KB yang mengutamakan penggalakkan penggunaan kontrasepsi tersebut disebut pula MKET (Metode Kontrasepsi Efektif Terpilih). Sugiri Syarief, Kepala Badan Koordinasi Keluarga Berencana Nasional Pusattahun 2006-2012 menyatakan pada masa otonomi daerah terjadi pelemahan program KB yang didukung oleh undang-undang yang tidak mendeskripsikan format koordinasi program tersebut. Meski demikian di tahun 2006, Presiden Susilo Bambang Yudhoyono merencanakan revitalisasi program keluarga berencana (dalam Burhani, 2010).

Kampanye kesehatan yang berlangsung selama lebih dari lima dekade ini menunjukkan adanya pola komunikasi kesehatan yang top down dari badan pemerintah ke masyarakat dengan cara koersif, hingga terlibatnya masyarakat sebagai agen komunikasi kesehatan. Periode orde baru menjadi periode pembiasaan atau kultivasi konsep Keluarga Berencana kepada masyarakat Indonesia. Selain pendekatan interpersonal melalui kader, posyandu, puskesmas dan tim dari BKKBN sendiri, BKKBN menggunakan iklan melalui media massa televisi. Riset Hutchinson dan Meekers (2012) menemukan bahwa penggunaan media massa dan komunikasi interpersonal dalam kampanye komunikasi kesehatan terkait perencanaan keluarga menghasilkan efek yang positif untuk menciptakan kesadaran publik terhadap kampanye tersebut. Hal ini menunjukkan bahwa penggunaan dua metode secara simultan berpotensi untuk menjangkau target sasaran kampanye secara lebih luas.

Beberapa iklan program KB (bkkbn.go.id) adalah Iklan KB Andalan yang menampilkan penggunaan dan manfaat alat kontrasepsi; Iklan KB Dua Anak
Lebih Baik, menampilkan beberapa artis yang mengkomunikasikan mengenai lebih baik memiliki dua anak; Iklan KB Pernikahan Dini. Iklan KB Pernikahan Dini mengangkat pesan perencanaan keluarga berdasarkan pada waktu dan kondisi yang tepat untuk menikah dan memiliki Anak; IklanKB Genre, Generasi Berencana ini menyasar usia Sekolah Menengah hingga Perguruan Tinggi, kampanye Genre ini mengangkat pentingnya perencanaan kehidupan remaja sampai usia menikah, yang bertujuan untuk pendewasaan usia pernikahan. Dari serangkaian iklan yang dibuat untuk program KB tersebut, iklan Dua Anak Lebih Baik dan Genre tidak menunjukkan penggunaan alat kontrasepsi. Perubahan visual iklan dari alat kontrasepsi yang sesuai digunakan untuk pasutri kepada penekanan terhadap perencanaan keluarga, menunjukkan adanya perubahan arah BKKBN dalam mengembangkan program Keluarga Berencana. Sangatlah menarik untuk mengamati bahwa periode pasca reformasi menunjukkan perubahan target sasaran program KB. Apabila pasutri menjadi sasaran program $\mathrm{KB}$ sejak periode Orde Baru hingga reformasi, maka pada pemerintahan SBY, sasaran program lebih meluas.

Newland (2001) menyoroti pergerakan politik dan kekuasaan yang melatarbelakangi berlangsungnya program KB di masa orde baru, yang ditunjukkan dengan koersi pemerintah dalam mencapai tujuan program untuk menekan laju pertumbuhan penduduk. Komunikasi oleh pemerintah menggunakan berbagai media yang menekankan komunikasi interpersonal langsung kepada penerima program. Sementara itu, iklan adalah media pendukung yang sangat penting dalam meningkatkan tingkat keaktifan penerima program dalam berinteraksi dengan pemberi program, seperti dalam penelitian Kim, Bazant, dan Storey (2007). Mereka meneliti Kampanye 'Smart Client, Smart Community' di daerah Sukabumi, Jawa Barat yang menemukan bahwa iklan media massa mendorong pasien untuk lebih aktif bertanya pada pemberi program KB.Berbeda dengan kampanye program KB pada masa Orde Baru,program KB pada masa pasca reformasidi awal pemerintahan SBY dinilai oleh berbagai pihak tidak berhasil. Seperti terungkap dari Syarief Sugiri (Kepala BKKBN tahun 2007-2013).

Presiden SBY dalam pidatonya di peringatan Harganas XIV tahun 2007 menyerukan revitalisasi untuk program $\mathrm{KB}$, "Hari ini kita hidupkan kembali program $\mathrm{KB}$, mulai sekarang dan kedepan. Saya instruksikan seluruh jajaran pemerintahan untuk mensukseskan revitalisasi program $\mathrm{KB}$ kepada 
gubernur, bupati dan walikota, dan semua pemimpin pemerintahan untuk tampil didepan menyukseskan program ini." (http://www.taputkab.go.id/page.php? news_id=515). Terlepas dari opini kegagalan program $\mathrm{KB}$ dan semangat revitalisasi yang digaungkan oleh Pemerintah SBY, sangatlah menarik untuk melihat bagaimana program KB direpresentasikan dalam iklan-iklan televisi program KB. Hal ini menarik untuk dilakukan karena media kampanye, dalam hal ini iklan, adalah sebuah alat komunikasi organisasi yang tidak terlepas dari budaya organisasi, dalam hal ini nilai-nilai politik, objektif pembuat pesan, dan alasan pemilihan target atau sasaran komunikasi.Untuk penelitian ini para peneliti tertarik bagaimana praktek ideologi dalam iklan KB pada tahun 2004-2014 sebagai bentuk komunikasi kesehatan pemerintah pada periode SBY. Analisis semiotika digunakan untuk membaca iklan melalui elemen adegan, dialog, gerak dan suara dalam iklan. Teori semiotic menjadi pisau untuk menganalisis cara kerja iklan, seperti yang ditemukan oleh Carty \& Peppin (2003),

"semiotic theory provide an analysis of the process by which advertising works, and allows us to move beyond the explicit claims to the implicit meanings called upon through the ad process itself. Drug ads convey conceptions of the drug and its effects on patients. Stereotypes and myths about social groups are used in the ads, which replicate inequalities in the social context.".

\section{TINJAUAN PUSTAKA}

\subsection{Komunikasi dan fungsi kesehatan sebagai proses komunikasi medis}

Komunikasi kesehatan menurut Zoller, Heater (2008. p. 3) mengemukakan bahwa komunikasi kesehatan mengarah pada jalannya proses komunikasi dan pesan yang menyelimuti isu kesehatan. Pengetahuan dalam bidang dapat dikategorikan berdasarkan penekanannya ke dalam dua kelompok besar yaitu prespektif berdasarkan proses dan prespektif berdasarkan pesan. Pendekatan berdasarkan proses menggali cara-cara yang didalamnya pemkanaan kesehatan, sedangkan prespektif berbasis pesan pesan terpusat strategis untuk menciptakan komunikasi yang efektif yang dapat mencapai tujuan para stakeholder kesehatan. Kondisi ini pada gilirannya memberikan pemahaman bahwa komunikasi kesehatan idealnya berdasar pada basis proses dan pesan. Seperti yang terjadi pada pemahaman sehat dan sakit bagi pelaku komunikasi. pemahaman ini merupakan inti dari pemikiran ilmu komunikasi. secara khusus mengambarkan proses individu dalam menggali cara-cara yang didalamnya terdapat pemaknaan kesehatan dan dapat diinterpretasikan secara simbolik.

Adapun fungsi komunikasi kesehatan bagi masyarakat terdapat beberapa hal, diantarannya; Diagnosis, komunikasi kesehatan yang diciptakan melalui diagnosis ini berupa dapat pendataan sebuah data yang dikumpulkan, dinnterpretasikan dan dipecahkan oleh beberapa tenaga media (dokter). Kedua komunikasi kesehatan sebagai fungsi kerjasama, tenaga medis (dokter) melakukan kegiatan komunikasi mengenai sifat penyakit seseorang dan implikasi tindakan untuk diberi resep atau tindakan pada upaya penyembuhan penyakit tersebut. Berikutnya, komunikasi kesehatan sebagai penasehat, yang mana tenaga medis melakukan komunikasi tarapeutik sebagai salah satu tujuan utama komunikasi interpersonal. Sedangkan yang terakhir fungsi kesehatan komunikasi adalah sebagai pendidikan yakni sebagai proses penyebaran informasi kepada individu dalam rangka upaya mengurangi risiko kesehatan dan untuk meningkatkan efektivitas pelayanan kesehatan (Infante, 1993. p.463).

\subsection{Faktor Pertimbangan Keberhasilan Kegiatan Kampanye Kesehatan}

Edward Bernays, salah satu Pioneers Public Relations di tahun 1891-1995, mengemukakan bahwa Public Relations merupakan "good work understood by the public". Bernays menjelaskan dalam peranannya, Public Relations harus memiliki dua formula yang terpenting.

First, a company or organization must do good work. It must produce quality product or provide a valuable service; it must have honest and productive relationship with its custmores, employees, and other constituent group ; and it must be socially responsible. The second part of of the formula requires letting people know about an organization's good work through various forms of communication, such as the new media, paid advertising, or in house publications.

Kampanye sebagai kegiatan melaui program yang dilakukan Public Relations, merupakan sebagai perwujudan dari tindakan komunikasi yang terencana dan mewujudkan untuk mempengaruhi khalayaknya. Seperti yang kita ketahui bahwa program kampanye dan Public Relations memiliki perbedaan pemahaman, Randy\& Ruth mengungkapkan bahwa kampanye 
Public Relations merupakan suatu kegiatan yang dilakukan untuk mempengaruhi khalayak serta mewujudkan tindakan dan aksi komunikasi dalam citra dan reputasi perusahaan.

A campaign without evaluation is waste of time and money, demikian ungkap Ostergaard, seorang pakar kampanye Jerman. Seperti yang kita ketahui bahwa kampanye adalah kegiatan yang melibatkan investasi besar, bukan hanya uang tapi juga sumber daya lainnya seperti waktu, tenaga, pikiran dan teknologi. Penyelenggaraan kampanye tidak ingin investasi ditanamkan sia-sia tanpa kejelasan tantang hasil yang dicapai.

\subsection{Periklanan sebagai Tools Dalam Kegiatan Kampanye Kesehatan}

Menurut Morrisan, 2010, p. 1 mengungkapkan bahwa periklanan merupakan iklan dan promosi merupakan bagian yang tak terpisahkan dari sistem ekonomi dan sosial masyarakat modern. Dewasa ini, iklan sudah berkembang menjadi sistem komunikasi yang sangat penting tidak saja bagi produsen barang dan jasa tetapi juga bagi konsumen. Kemampuan iklan dan metode promosi lainnya dalam menyampaikan pesan kepada konsumen menjadikan kedua bidang tersebut memegang peran sangat penting bagi keberhasilan persuahaan. Berbagai bentuk usaha, mulai dari usaha eceran hingga perusahaan multinasional, mengadalkan iklan dan promosi untuk membantu mereka memasarkan barang dan jasa. Semakin meningkat pengeluaran (belanja) iklan dan promosi yang dilakukan perusahaan menjadi bukti bahwa tenaga pemasaran di manapun di dunia mengakui pentingnya kegiatan iklan dan promosi.

Tiada istilah tunggal jelas dan menyeluruh yang bisa menggambarkan karakter kompleks periklanan dan fungsi-fungsinya yang majemuk dan saling terkait. Sering kali diklasifikasikan dalam beberapa tipe besar, menurut Monle Lee dalam bukunya Periklanan dalam Prespektif Global yakni: Periklanan produk yakni porsi utama mengeluarkan periklanan dibelanjakan untuk produk. Presentasi dan promosi produk-produk baru, produk-produk yang ada dan produk-produk hasil revisi. Periklanan Eceran yakni berlawanan dengan iklan produk, periklanan eceran bersifat lokal dan berfokuspada toko, tempat dimana beragam produk dapat dibeli atau di mana satu jasa ditawarkan. Periklanan eceran memberikan tekanan pada harga, ketersediaan, lokasi, dan jam-jam operasi. Periklanan Korporasi merupakan fokus perikalanan ini adalah membangun identitas korporasi atau untuk mendapatkan dukungan publik terhadap sudut pandang organisasi. Kebanyakan perikalan korporasi dirancang untuk menciptakan citra menguntungkan bagi sebuah perusahaan dan produk-produknya.

Berikutnya adalah Periklanan Bisnis ke bisnis merupakan sebuah istilah iniberkaitan dengan perikalan yang ditujukan kepada para pelaku industri (ban yang diiklankan kepada manufaktur mobil), para pedagang perantara (pedagang partai besar dan pengcer) serta para profesional (seperti pengacara dan akuntan). Periklanan oleh para profesional telah mendapatkan momentum sejak keputusan Mahkamah Agung Amerika Serikat memperbolehkan perikalanan semacam ini. Periklanan politik yakni Perikalan politik sering kali digunakan para politisi untuk membujuk orang untuk memilih mereka, dan karenanya, iklan jenis ini merupakan sebuah bagian penting dari proses politik di Amerika Serikat dan negara-negara demokrasi lain yang memperbolehkan iklan para kandidat. Para pengkritik merasa prihatin bahwa periklanan politik cenderung lebih berfokus pada citra ketimbang isuisu. Sedangkan Perikalanan direktori yakni Orang merujuk periklanan direktori untuk menemukan cara membeli sebuah produk atau jasa. Bentuk terbaik direktori yang dikenal adalah yellow pages, meskipun sekarang terdapat berbagai jenis direktori yang menjalankan fungsi serupa. Periklanan respon langsung yakni Periklanan respon langsung melibatkan komunikasi dua arah di antara pengiklan dan konsumen. Periklanan tersebut dapat menggunakan sembarang media periklanan (pos, televisi, koran, atau majalah), dan konsumen dapat menanggapinya, sering kali lewat pos, telepon atau faks. Banyak perusahaan sekarang memperbolehkan konsumen menanggapi secara online. Produk biasanya dikirimkan ke konsumen lewat pos. Perikalan pelayanan masyarakat yakni Perikalan pelayanan masyarakat dirancang untuk beroperasi untuk kepentingan masyarakat dan mempromosikan kesejahteraan masyarakat. Iklan-iklan ini diciptakan bebas biaya oleh para profesional periklanan, dengan ruang dan waktu iklan merupakan hibah oleh media. Dan terakhir adalah Periklanan advokasi, periklanan advokasi berkaitan dengan penyebaran gagasan-gagasan dan klasifikasi isu sosial yang kontroversial dan menjadi kepentingan masyarakat.

\subsection{Membaca Tayangan Televisi Sebagai Text}

Dalam penelitian ini, penggunaan semotika dipakai sebagai metode. Prespektif semiotika merupakan salah satu alat atau metode yang sangat penting dalam penggunaan sebuah riset. Smith dalam bukunya 
Cited, 1995 mengungkapkan bahwa : "Semoticts has been an important tool of research to reveal hidden meaning behind a text'. Fokus dari prespektif semiotika memiliki banyak aspek dari simbol dan tanda komunikasi. Barthes $(1973,1977)$, the semiotics approach asked two fundamental quetions : "the quetions of representation". Dalam karyanya, Television Culture, John Fiske (dalam Berger, 2005) menerangkan bahwa teks televisi bersifat ambigu, bahwa televisi bersifat polisemik yakni penuh kode dan tanda. Tanda menurut Saussure adalah kombinasi dari konsep dan citra suara (sound image), kombinasi yang tidak dapat dipisahkan.

\subsection{Program Keluarga Berencana (KB) Dalam Wujud Kegiatan Komunikasi Pemerintah Melalui Badan Kependudukan Keluarga Berecana Nasional (BKKBN)}

Tujuan utama pelaksanaan keluarga berencana dalam Repelita I adalah untuk meningkatkan derajat kesehatan dan kesejahteraan ibu dan anak, keluarga serta masyarakat pada umumnya. Dengan berhasilnya pelaksanaan keluarga berencana diharapkan angka kelahiran dapat diturunkan, sehingga tingkat kecepatan perkembangan penduduk tidak melebihi kemampuan kenaikan produksi. Dengan demikian taraf kehidupan dan kesejahteraan rakyat diharapkan akan lebih meningkat.

Program keluarga berencana dilaksanakan atas dasar suka- rela serta tidak bertentangan dengan agama, kepercayaan dan moral Pancasila. Dengan demikian maka bimbingan, pendidikan serta pengarahan amat diperlukan agar masyarakat dengan kesadarannya sendiri dapat menghargai dan, menerima pola keluarga kecil sebagai salah satu langkah utama untuk meningkatkan kesejahteraan hidupnya. Oleh karena itu pelaksa-naan program keluarga berencana tidak hanya menyangkut masalah tehnis medis sematamata, melainkan meliputi berbagai segi penting lainnya dalam tata hidup dan kehidupan masyarakat.

Organisasi pelaksanaan keluarga berencana dalam Repelita I mengalami perkembangan-perkembangan. Kegiatan secara terorganisir mulai dirintis dengan didirikannya Perkumpulan Keluarga Berencana Indonesia (PKBI) pada tahun 1957. Akan tetapi barulah sejak tahun 1968 dengan dibentuknya Lembaga Keluarga Berencana Nasional (LKBN), kegiatan keluarga berencana telah ditingkatkan menjadi suatu program nasional. Sesuai dengan perkembangan pelaksanaan keluarga berencana, dibutuhkan (penyempurnaan organisasi, sehingga dalam tahun
1970 LKBN telah dirubah menjadi Badan Koordinasi Keluarga Berencana Nasional (BKKBN). Selanjutnya dalam Repelita I terus dilakukan usaha-usaha penyempurnaan organisasi BKKBN.

Untuk lebih mengembangkan pelaksanaan program keluarga berencana dalam Repelita I telah dimanfaatkan pula berbagai bantuan luar negeri yang serasi dengan pola kebijaksanaan nasional untuk program keluarga berencana.

Selama masa Repelita I pelaksanaan program keluarga berencana di pusatkan di daerah Jawa dan Bali. Di daerah-daerah tersebut terdapat situasi kepadatan penduduk yang relatif lebih kritis keadaannya dibandingkan dengan daerah lainnya di Indonesia. Walaupun demikian ternyata bahwa di beberapa daerah di luar Jawa dan Bali selama masa Repelita I telah dirintis pula usaha pelaksanaan keluarga berencana oleh pelbagai organisasi kemasyarakatan serta Pemerintah Daerah yang bersangkutan.

Pelaksanaan program keluarga berencana dalam Repelita I terutama meliputi kegiatan penerangan dan motivasi, pelayanan medis, pendidikan dan latihan, pengembangan logistik, pencatatan dan pelaporan serta penelitian dan penilaian kegiatan keluarga berencana.

\section{METODE PENELITIAN}

Metode yang digunakan dalam penelitian ini ialah semiotika, yang mengidentifikasi, mengeksplorasi serta menganalisa tanda-tanda, sign atau image yang berada dalam sebuah teks. Oleh karenanya penelitian ini menggunakan pendekatan kualitatif, yang memungkinkan peneliti untuk menganalisa dan menjelaskan kemasan interpretif yang memberi makna dibalik suatu pesan.

Pilihan tayangan iklan Keluarga Berencana sebagai sampel dalam penelitian ini guna memberikan sebuah gambaran yang komprehensif tentang sebuah representasi Perencanaan Keluarga era kepemimpinan SBY. Representasi tersebut dijelaskan melalui tandatanda atau simbol yang digunakan dalam tayangan iklan Keluarga Berencana sekaligus mendeskripsikan makna di balik dalam iklan Keluarga Berencana.

Paradigma yang digunakan dalam penelitian ini ialah interpretatif. Paradigma ini melihat bahwa subyek sebagai faktor sentral dalam kegiatan wacana serta hubungan-hubungan sosialnya. Setiap pernyataan pada dasarnya adalah tindakan penciptaan makna, 
oleh karenanya tujuan paradigma interpretatif adalah untuk mengungkapkan bagaimana sebuah makna diciptakan, dipelihara dan mengalami suatu perubahan.

\section{PEMBAHASAN}

Indonesia merupakan sebuah negara berkembang dengan jumlah peningkatan penduduk yang tinggi. Hasil sensus menurut publikasi BPS pada agustus 2010 menyebutkan bahwa jumlah penduduk Indonesia adalah 237.556 .363 orang, terdiri atas 119.507.600 pria dan 118.048 .783 wanita, dengan laju pertumbuhan 1,49 persen per tahun. Pertumbuhan penduduk ini tentu saja berimplikasi secara signifikan terhadap perkembangan ekonomi dan kesejateraan negara (Koes Irianto, 2014).

Dari gambaran tersebut pemerintah mengambil suatu langkah antisipasi untuk menekan tingginya laju pertumbuhan penduduk. Pemerintah melalui Badan Kependudukan dan Keluarga Berencana Nasional (BKKBN) merealisasikan peranannya dalam partumbuhan penduduk melalui tugas promosi berupa, melibatkan tokoh masyarakat, pemerhati keluarga berencana dan pelayanan kontrasepsi sebagai komunikasi informasi dan edukasi masyarakat. Adapun tujuan dari peranan ini adalah membuat manusia bahagia, sehat, dan sejahtera.

Menurut Koes Irianto dalam bukunya Pelayanan Keluarga Berencana (2014), terdapat pengertian tentang keluarga berencana yakni:

Keluarga Berencana (KB) merupakan suatu program pemerintah yang dirancang untuk menyeimbangkan antara kebutuhan dari jumlah penduduk. Program keluarga berencana oleh pemerintah adalah agar keluarga sebagai unit terkecil kehidupan bangsa diharapkan menerima Norma Keluarga Kecil Bahagia dan Sejahtera (NKKBS) yang berorentasi pada pertumbuhan yang seimbang. Adapun tujuan dari program keluarga berencana ini adalah meningkatkan kesejahteraan ibu, anak dalam rangka mewujudkan NKKBS (Norma Keluarga Kecil Bahagia dan Sejahtera)

Jadi, dari pengertian tersebut dapat dijelaskan bahwa program keluarga berencana merupakan suatu program yang menunjang pertumbuhan penduduk yang berkualitas. Kualitas penduduk yang baik sangat menentukan keberhasilan pembangunan dan kemajuan suatu negara.
Program KB di Indonesia dimulai sekitar tahun 1957. Pada tahun tersebut didirikan perkumpulan keluarga berencana (PKB). Pada saat itu program KB masuk ke Indonesia melalui jalur urusan kesehatan (bukan urusan kependudukan). Belum ada political will dari pemerintah saat itu. Program KB masih dianggap belum terlalu penting. Kegiatan penyuluhan dan pelayanan masih dianggap belum penting. Kegiatan penyuluhan dan pelayanan masih terbatas dilakukan karena masih ada pelanggaran tentang penyebaran metode dan alat kontrasepsi. Begitu masuk dalam orde baru, program KB mulai menjadi perhatian pemerintah. Saat itu PKBI (Persatuan Keluarga Berencana Indonesia) sebagai organisasi yang mengelola dan concern terhadap program KB mulai diakui sebagai badan hukum oleh departemen kehakiman. Pemerintah orde baru yang menitikberatkan pada pembangunan ekonomi, mulai menyadari bahwa program KB sangat berkaitan erat dengan pembangunan ekonomi. Kemudian pada tahun 1970 resmilah program $\mathrm{KB}$ menjadi program pemerintah dengan ditandai pencanangan hari keluarga pada tanggal 29 Juni 1970. Pada tanggal tersebut pemerintah mulai memperkuat dan memperluas program KB ke seluruh Indonesia. (Yetti Anggraini : 2011)

Sampai saat ini, program keluarga berencana di Indonesia merupakan contoh program yang paling berhasil di dunia. Meski begitu laju pertumbuhan dan jumlah penduduk di Indonesia masih meningkat. Karena itu, program KB harus tetap dikembangkan. Dalam usaha mencapai tujuan dan target yang telah ditetapkan dalam kebijaksanaan dan strategi gerakan KB Nasional, maka pola operasional diarahkan pada : peremajaan segmentasi berpijak dari diri kependudukan Indonesia yang mempunyai struktur umur penduduk muda, maka kebijaksanaan dan strategi operasional harus searah dengan ciri kependudukan yang ada tersebut.

Dalam usaha mencapai tujuan program keluarga berencana, BKKBN melakukan kegiatan komunikasi informasi dan edukasi. Menurut Effendy (1998), komunikasi adalah pertukaran pikiran atau keterangan dalam rangka menciptakan rasa saling mengerti dan saling percaya, demi terwujudnya hubungan yang baik antara seseorang dengan orang lain.

Dalam komunikasi inilah, pentingnya komunikasi kesehatan. Komunikasi kesehatan menurut Zoller, Heater (2008, p. 3) mengemukakan bahwa komunikasi kesehatan mengarah pada jalannya proses komunikasi dan pesan yang menyelimuti isu kesehatan. 
Kondisi ini memberikan pemahaman bahwa pentingnya komunikasi kesehatan idealnya berdasar pada basis proses dan pesan. BKKBN menerapkan komunikasi kesehatan ini berupa KIE yakni Komunikasi, Informasi dan Edukasi, yang mana bertujuan untuk mendorong terjadinya perubahan perilaku kearah yang positif, peningkatan pengetahuan, sikap dan praktik (klien) secara wajar sehingga masyarakat melaksanakan secara mantap sebagai perilaku yang sehat dan bertanggung jawab. Salah satu bentuk komunikasi kesehatan yang mereka lakukan adalah penggunaan iklan sebagai media massa yang menjadi promosi kesehatan. Seperti yang dikemukakan oleh Corcoran (2013:73) bahwa:

Penggunaan media massa merupakan salah satu alat dalam promosi kesehatan. Media massa merupakan sebuah mekanisme dalam pemberitaan informasi dan komunikasi, salah satunya adalah televisi. Televisi merupakan sumber utama sebagai media informasi tentang isu kesehatan.

Dari pendapat Corcoran menunjukkan bahwa televisi memiliki efek positif dalam promosi kesehatan, hal ini memberikan efek kognitif, afektif dan konatif bagi publiknya melalui iklan.

Berdasarkan temuan, iklan-iklan Keluarga Berencana yang diproduksi oleh BKKBN merupakan kegiatan persuasi pemerintah dalam mengendalikan jumlah penduduk. BKKBN dalam hal ini lebih memainkan peran sebagai public relations yang menghubungkan dan membangun awareness publik mengenai kesehatan reproduksi dan mengajak publik untuk terlibat dalam program Keluarga Berencana. Dalam scene-scene iklan Keluarga Berencana, BKKBN lebih banyak menggunakan narasi sebagai pendekatan budaya untuk melakukan persuasi serta partisipasi publik.

Larkey dan Hill (2012:96) menjelaskan bahwa narasi ditarik dari kelompok masyarakat yang digunakan untuk membangun kesadaran, menyuarakan pesan dan kearifan yang berasal dari masyarakat, mengidentifikasikan bagaimana kelompok mempersepsikan konstelasi nilai, kepercayaan, perilaku yang terkait dengan kesehatan serta memilah cerita terbaik untuk menceritakan tujuan promosi kesehatan.

Dalam iklan Keluarga Berencana, keluarga sebagai pranata sosial yang memberikan kontribusi bagi perkembangan seseorang menjadi narasi utama dalam iklan-iklan KB BKKBN. Keluarga yang terencana akan menghasilkan keluarga yang sehat dan anak- anak yang bahagia. Keluarga yang bahagia dalam iklan-iklan KB dideskripsikan sebagai keluarga yang terpenuhi kebutuhannya baik sandang, pangan maupun papan. Mencapai keluarga yang bahagia bisa dilakukan apabila pasangan suami istri memiliki perencanaan yang baik untuk mengenai kapan memiliki anak. Keluarga dalam iklan KB dikonstruksikan sebagai entitas penting dalam pembangunan sebuah bangsa. Keluarga merupakan pranata sosial yang menghasilkan generasi-generasi.
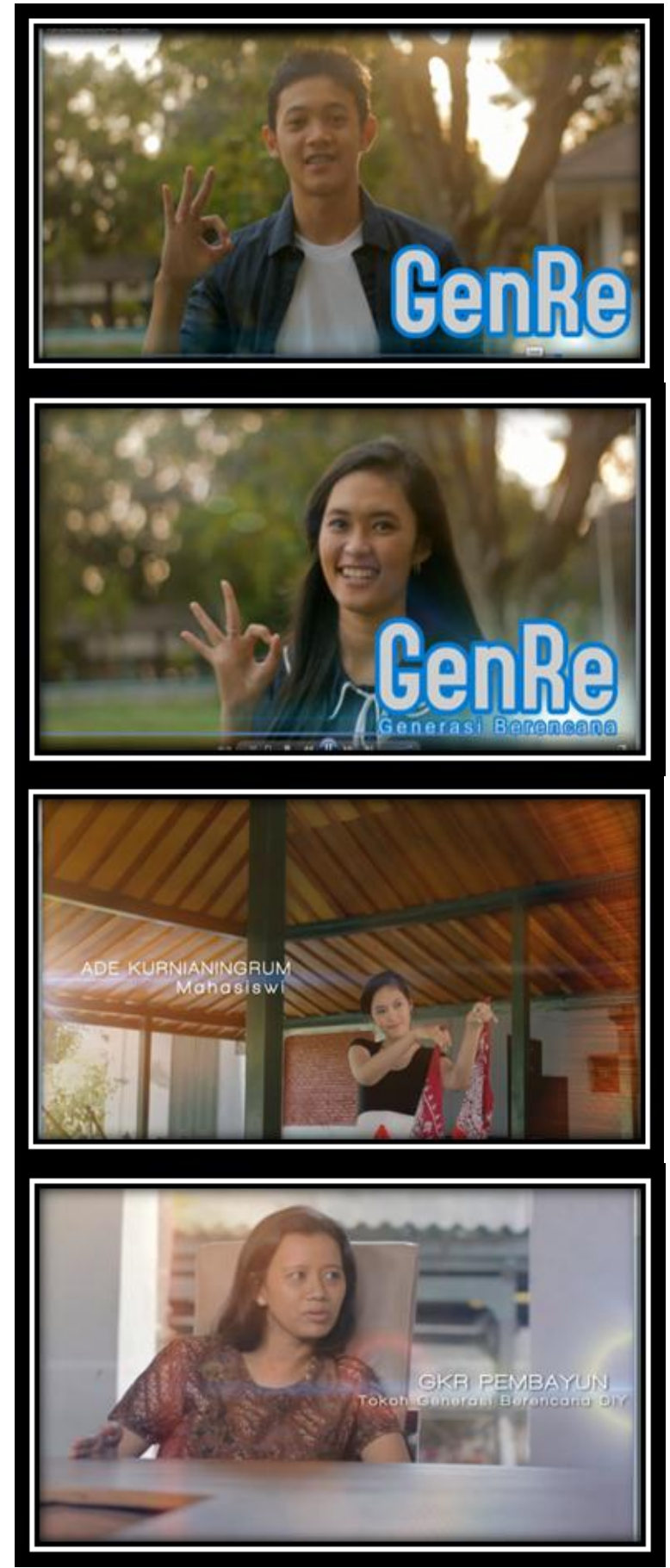

Gambar 1. Potongan Iklan KB Generasi Berencana 


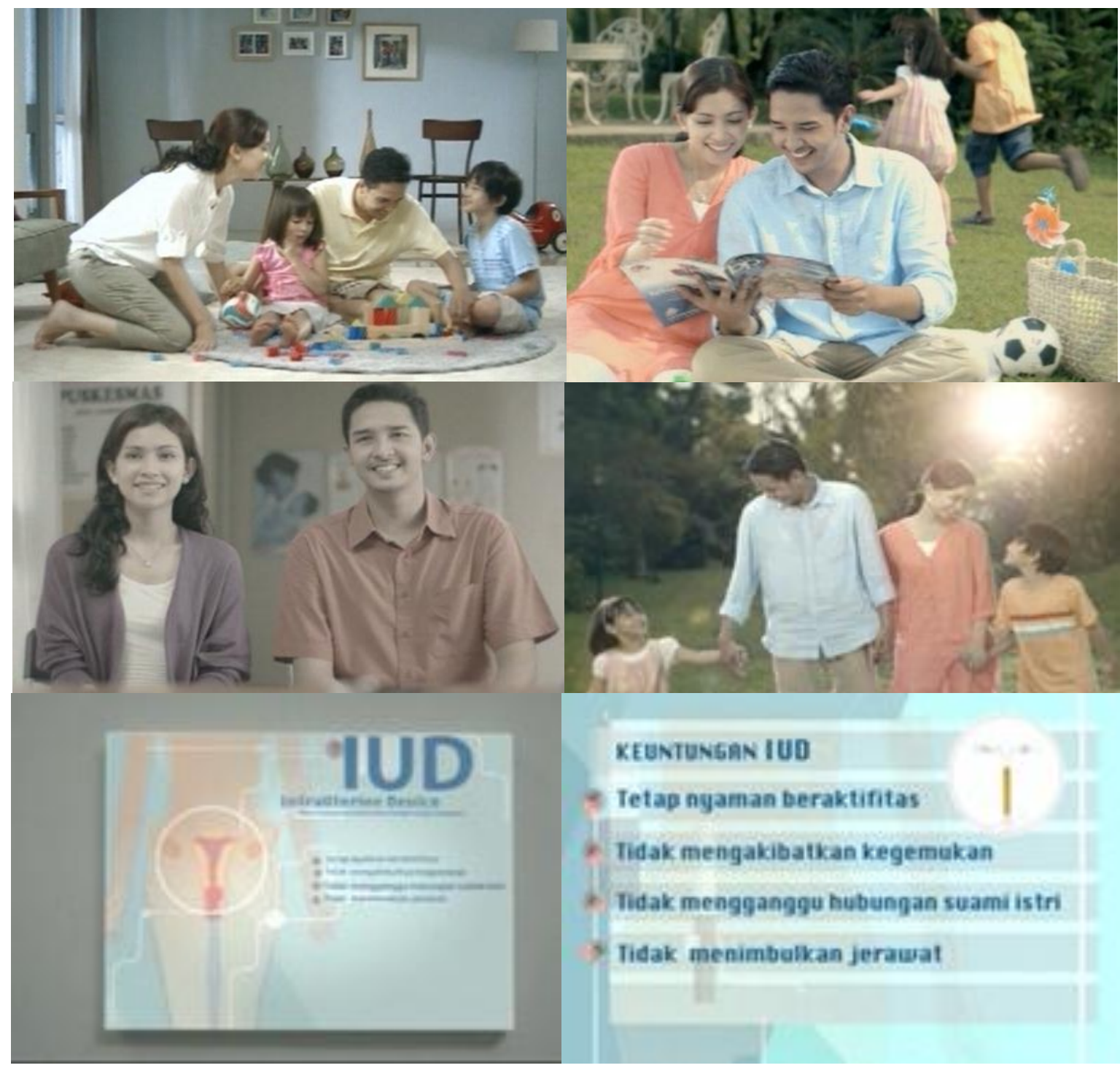

Gambar 2. Potongan Iklan KB Keluarga Kecil Bahagia

Selain narasi tentang keluarga, iklan-iklan KB juga menunjukkan peranan perempuan yang dominan dalam sektor domestik. Scene-scene tersebut menarasikan keterlibatan perempuan dalam membangun keluarga. Iklan-iklan KB terlihat menempatkan perempuan dan laki-laki dalam posisi yang berbeda. Politik gender kemudian diterapkan dalam politik kependudukan ini. Sekalipun dalam beberapa scene, ditunjukkan bahwa perempuan juga dilibatkan dalam pengambilan keputusan reproduksi kesehatan.

Setiyaningrum dan Aziz (2014:11) memaparkan cara melibatkan perempuan dalam pengambilan keputusan antara lain, pertama, memberikan informasi yang selengkap-lengkapnya tentang permasalahan sesuai kebutuhan. Kedua, membrikan pandangan-pandangan tentang akibat dari keputusan apapun yang akan diambilnya. Ketiga, menyakinkan ibu untuk bertujuan terhadap keputusan yang akan diambilnya. Keempat, pastikan bahwa keputusan yang diambil ibu adalah yang terbaik serta memberi dukungan pada ibu atas keputusan yang diambilnya.

Melalui program keluarga berencana, pada pemerintahan Susilo Bambang Yudyoyono (SBY) ini, BKKBN mengajak peran serta masyarakat untuk berpartisipasi dalam perwujudan pertumbuhan dan kepadatan penduduk yang ideal dengan cara meningkatkatkan kualitas keluarga dengan kepedulian dan eran serta masyarakat dalam pendewasaan usia perkawinan serta perencanaan keluarga. Melalui iklan $\mathrm{KB}$ tersebut, masyarakat Indonesia mampu merencanakan keluarga yang ideal serta menggalakan pertumbuhan keluarga kecil bahagian dan sehat. 


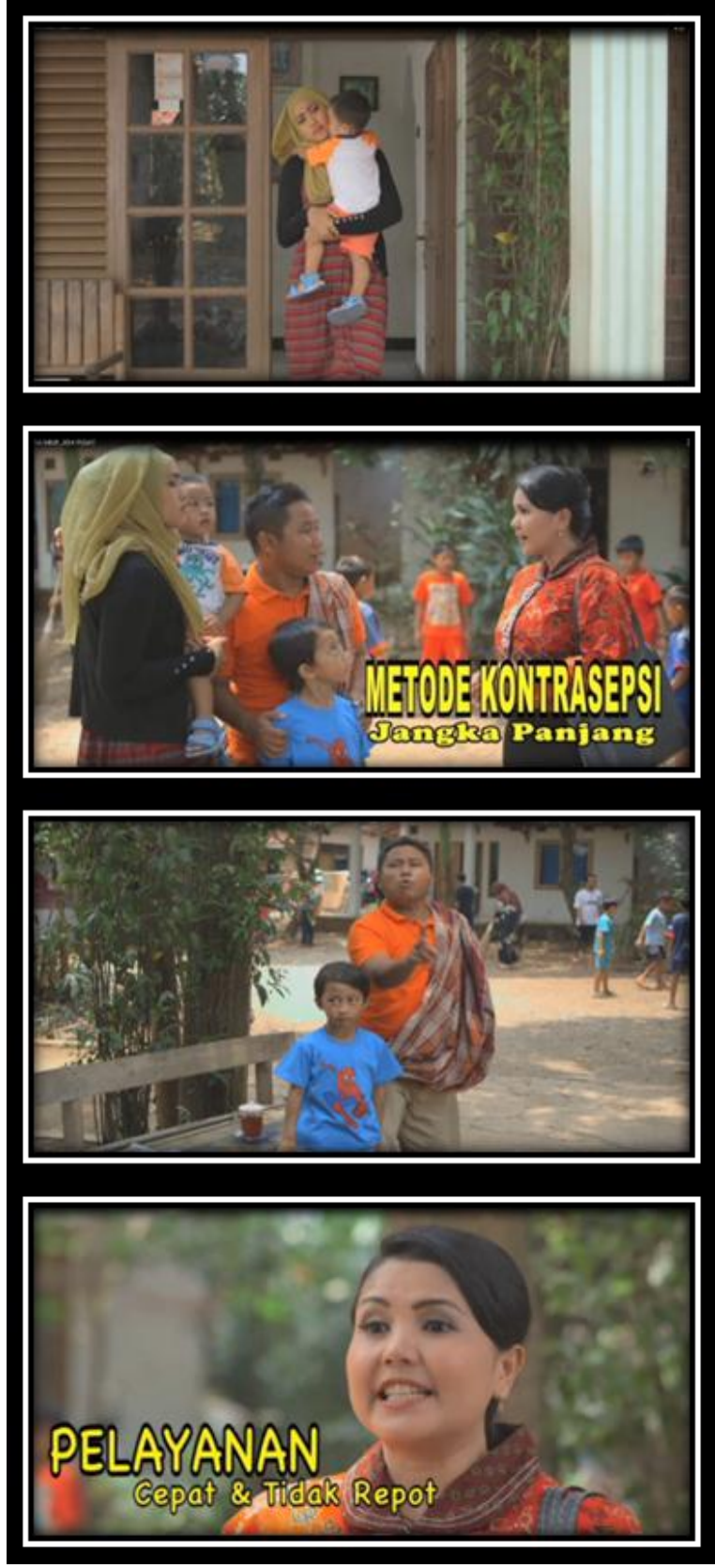

Gambar 3. Potongan Iklan KB MKJP (Metode Kontrasepsi Jangka Panjang

Dilihat dari aspek public relations, Edward Bernays memiliki dua formula sebagai perwujudan dari tindakan komunikasi yang terencana untuk mempengaruhi khalayaknya yakni melalui kampanye. Randy \& Ruth mengungkapkan bahwa kampanye public relations merupakan suatu kegiatan yang dilakukan untuk mempengaruhi khalayaknya. Dalam prespektif ini, iklan KB merupakan suatu program yang dibuat oleh BKKBN untuk mewujudkan peran serta pertumbuhan keluarga kecil bahagia dan sehat, baik melalui iklan Pernikahan Dni, Bina Keluarga Balita, Generasi berencana, Metode Kontrasepsi dan sebagainya. Kegiatan ini diarahkan untuk menciptakan perubahan pada tataran kognitif (pengetahuan), sikap, serta perilaku khalayak yang terukur.

Dengan media Iklan, metode yang diyakini mampun mengubah persepsi dan perilaku masyarakat ini, iklan $\mathrm{KB}$ ini merupakan suatu alat promosi yang menyampaikan pesan penting tentang keberhasilan suatu negara yakni pertumbuhan penduduk yang ideal serta masyarakat yang sehat.

Iklan yang dibuat oleh BKKBN ini menampilkan banyak sekali pesan yang diungkapkan. Dalam hal ini secara eksplisit terlihat dari dukungan berbagai para ambassador atau public figure sebagai bagian yang mempresentasikan suatu keluarga bahagia. Bahkan produk, produk diluaran. Pentingnya para tokoh yang diwujudukan melalu para selebriti ini diyakini ditentukan oleh beberapa hal.

Menurut Simatupang (2004), pemilihan celebrity endorse ini ditentukan oleh familiarity relevance, esteem, dan differentiation. hal ini dapat dilihat dari beberapa iklan diatas, beberapa celebrity endorse yang menjadi bagian dalam iklan tersebut sangat menguatkan pesan iklan yang ingin disampaikan. Misalnya, Narji dalam iklannya MKJP, sosoknya yang low profile tergambar dalam masyarakat dari kelas menengah bawah yang sangat mengingkan banyak anak, hal ini sangat memrepresentasikan sosok tersebut, dengan prbadi yang tulus dan menyenangkan, kita sebagai audience bisa terpersuasi untuk percaya dengan pesan yang ia sampaikan. Dalam hal ini, Narji mewakili Familirty dan Diferentiation dalam iklan tersebut yakni, mengenal sosok artis yang memiliki pribadi menyenangkan dan masyarakat melihat bahwa Narji adalah pribadi yang unik atas produk yang dimilikinya.

Pesan pemerintah adalah generasi muda menjadi generasi yang mulai merencanakan kehidupan mereka, tidak hanya pendidikan dan pekerjaan namun juga usia perkawinan. Generasi muda digambarkan dapat terancam kehilangan periode aktif, produktif dan kreatif mereka apabila menikah terlalu dini. Generasi yang produktif itulah yang nantinya wajib diproyeksikan menjadi orang-orang lanjut usia yang mandiri dan berdaya guna.

Arundhati Char (2011) dalam studinya mengenai Male Involvement in Family Planning and Reproductive Health in Rural Central India, menjelaskan pada 1980-an, ada sebuah pengakuan tersembunyi bahwa pria itu merupakan faktor penting dalam kesehatan perempuan dan anak-anak. 

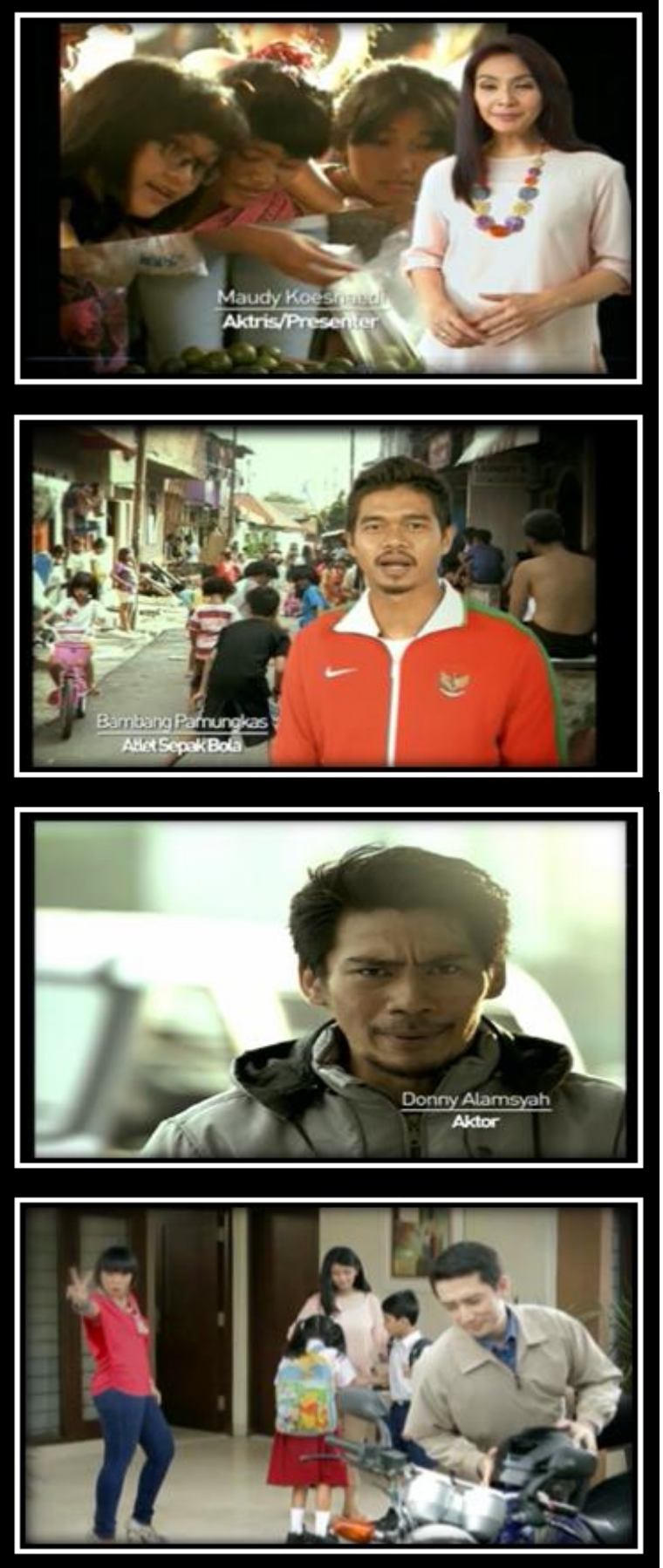

Gambar 4. Potongan Iklan KB "Celebrity Endoser"

Hasil penelitian menunjukkan bahwa laki-laki tidak hanya bertindak sebagai 'gate keeper' bagi akses pelayanan kesehatan anak-anak tetapi juga memiliki pengaruh langsung pada kesehatan pasangan mereka dan anak-anak mereka (Gallen et al., 1986). Pria sering diidentifikasi memiliki sikap acuh tak acuh dan tidak peduli tentang kesejahteraan pasangan mereka sehingga kemudian muncul strategi agar para pekerja kesehatan mulai bekerja secara langsung dengan perempuan di masyarakat sebagai sarana untuk memberdayakan mereka dan melindungi mereka dari efek perilaku laki-laki. Strategi ini terutama difokuskan di bidang kesehatan seksual dan reproduksi (Sternberg dan Hubley 2004 Stycos 1996). Pada akhir 1980-an, fokus pemberdayaan perempuan menjadi kekuatan pendorong penting dalam mempromosikan kesehatan dan, lebih khusus, dalam promosi kesehatan seksual (Stein 1997). Namun, strategi ini memberdayakan perempuan tanpa partisipasi aktif laki-laki digambarkan sebagai solusi parsial yang bisa mengasingkan lebih banyak orang (Sternberg dan Hubley, 2004). Ketakutan ini, ditambah dengan pemahaman tentang hubungan kekuasaan antara jenis kelamin dalam masyarakat menyebabkan keyakinan yang kuat dalam keterlibatan laki-laki dalam promosi kesehatan (Cornwall dan Black 2000 Drennan 1998).

International Conference on Population and Develompent (ICPD) pada 1994 menegaskan peran gender sangat diperkuat dalam keyakinan dan praktik budaya, dan konstruksi sosial maskulinitas dan feminitas mendalam membentuk seksualitas, preferensi reproduksi, dan praktek kesehatan (PBB 1994). Hubungan gender yang tidak setara sering dikaitkan dengan usia dini di pernikahan perempuan dan perbedaan yang besar dalam umur, pendidikan dan pendapatan antara pasangan (Narayan et al. 2000a, Narayan et al. 2000b). Tingkat ketidakseimbangan dalam hubungan gender dalam rumah tangga akhirnya tercermin dalam status perempuan dalam rumah tangga dan pemanfaatan informasi, pendidikan, dan pendapatan dan, lebih umum, atas kehidupan mereka dan lingkungan, termasuk kesuburan, seksual dan kesehatan reproduksi.

Politik gender dalam penyampaikan pesan-pesan keluarga berencana sudah mengakar terutama di era Orde Baru. Era SBY, kemudian bersifat melanggengkan serta meneruskan saja kebijakan Orde Baru. Tidak ada rumusan maupun terobosan yang signifikan mengenai keluarga berencana di era SBY (20042014). Idealisme keluarga dengan dua anak merupakan karakter ideologi Pembangunan yang telah diterapkan oleh Suharto. Keluarga modern kemudian di era SBY digambarkan sebagai keluarga dengan dua anak. Ibu tetap menjalani peran sebagai penguasa domestik yang bertanggung jawab pada pertumbuhan anak sekalipun dalam scene-scene iklan KB, perempuan mulai memiliki nilai tawar dalam menentukan jumlah anak yang akan dimiliki. Patriarkhisme dalam perencanaan keluarga dalam konteks ini lebih bersifat moderat ketika suara perempuan sebagai second class menjadi pertimbangan menentukan keputusan. 


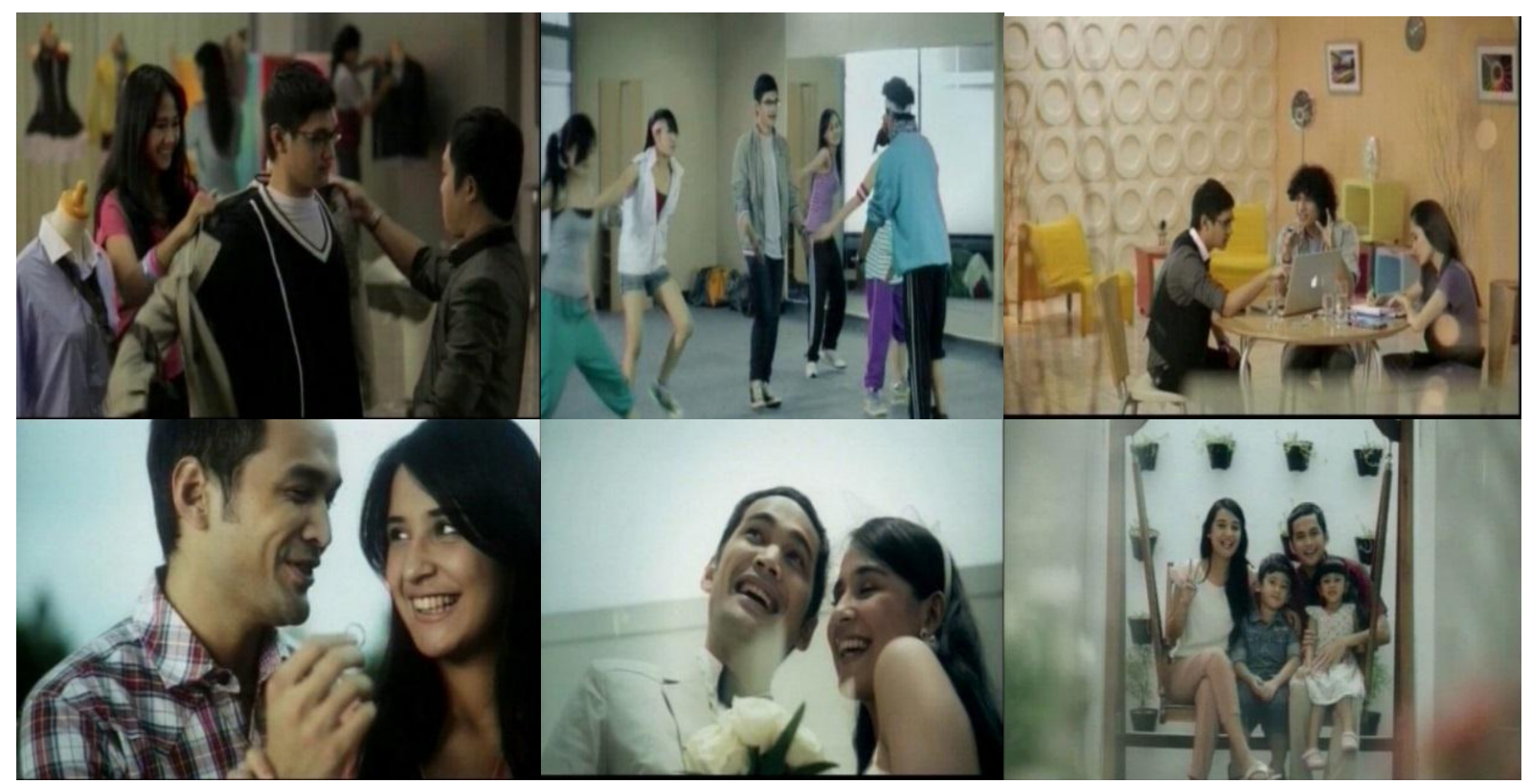

Gambar 5. Potongan Iklan KB Generasi Berencana \& Pernikahan Dini

\section{KESIMPULAN}

Berdasarkan temuan data, program pengelolaan kepadatan penduduk ini dianggap lebih baik pada masa orde baru. Pada pemerintahan Susilo Bambang Yudhoyono, BKKBN selaku pengelolanya berdiri secara mandiri dan tidak berada di bawah departemen apapun. Hal ini mengindikasikan adanya independensi lembaga dari pemerintah yang selama ini mengatur program tersebut. Meskipun demikian, muncul indikasi meningkatnya jumlah penduduk yang bersumber dari minimalnya edukasi kepada masyarakat mengenai jumlah anak yang sesuai untuk menunjang kesejahteraan keluarga. Jadi, Keluarga Berencana merupakan produk dari sinergisme ideologi pembangunan Orba dan patriarkhis. KB sejak era Orba merupakan instrumen Negara untuk mengatur dan mengendalikan jumlah penduduk. Pada era SBY, kebijakan ini masih diiterapkan sekalipun bersifat lebih humanis bagi perempuan. Dalam scene-scene di atas menunjukkan bahwa perempuan tidak lagi ditempatkan sebagai obyek dalam kesehatan reproduksi namun kedudukan dengan laki-laki juga digambarkan lebih setara. Sekalipun tidak dapat disebut sebagai gerakan feminism namun iklan KB jauh lebih civilized bagi perempuan.

Melalui program keluarga berencana, pada pemerintahan Susilo Bambang Yudyoyono (SBY) ini, BKKBN mengajak peran serta masyarakat untuk berpartisipasi dalam perwujudan pertumbuhan dan kepadatan penduduk yang ideal dengan cara meningkatkatkan kualitas keluarga dengan kepedulian dan eran serta masyarakat dalam pendewasaan usia perkawinan serta perencanaan keluarga.

\section{DAFTAR PUSTAKA}

Alifahmi, Hifni. 2005. Sinergi Komunikasi Pemasaran. Bandung: Mizan Media Utama.

Abu Bakar, Sukawati. 2011. Kesehatan Reproduksi dan Keluarga Berencana. PT. Raja Grafindo Persada: Jakarta

Anggriani, Yetti. 2011. Pelayanan Keluarga Berencana. Rohima Pers: Yogyakarta

Bobbit, Randy \& Sullivan, Ruth. 2009. Public Relations Campaign. United Stade of America: Pearson

Botan, Carl \& Hazleton, Vincent. 2006. Public Relations Theory II. Lawrence Erlbaum Associates, Publisher: New Jersey.

Burhani, R. 2010, http://www.antaranews.com/berita/ 171800/program-kb-di-masa-orba-lebih-diakui

BKKBN. 2008. Bunga Rampai Gerakan KB Nasional: Mewujudukan Keluarga Kecil Bahagia dan Sejahtera. KBBKN: Jakarta.

Badley Wright, Kevin. 2014. Health Communication in the 21 st century. Wiley-Blackwell: USA

Carty, E., \& Peppin, P. 2003. Signs of inequality: Constructing disability in antidepressant drug advertising. Health Law Journal, 161-184. Retrieved from http://search.proquest.com/ docview/212116936? accountid $=45762$

Corcoran, N. (Ed.). 2013. Communication health: Strategies for health promotion (2nd ed.). London: Sage Publications. 
Cho, Hyunyi. 2012. Helath Communication Message Design. Sage Publication, Inc.: London.

Fiske, Jhon. 2003. Reading Television. London: Routledge.

Gregory, A. 2010. Planning and managing public relations campaign (3rd ed.). London: Kogan Page.

Hutchinson , P. L., \& Meekers, D., 2012, Estimating Causal Effects from Family Planning Health Communication Campaigns Using Panel Data: The 'Your Health, Your Wealth' Campaign in Egypt. PloS ONE 7(9): e46138. doi:10.1371/ journal.pone.0046138.

Heath, Robert L. 2005. Encyclopedia of Public Relations. Sage Publication, Inc: London.

Infate, Dominic A. \& Rancer, Andrew. 1993. Building Communication Theory. Waveland Press, Inc: United States America.

Irianto, Koes. 2014. Pelayanan Keluarga Berencana. Alfabeta: Bandung.

Jurnal Keluarga, Edisi Pertama 2015. Melaju Bersama Program Kependudukan, KB dan Pembangunan Keluarga. Jakarta.

Kim, Y. M., Bazant, E., \& Storey, D. D., (2007), Smart patient, smart community: improving client participation in family planning consultations through a community education and mass-media program in Indonesia, Int'l. Quarterly of Community Health Education, Vol. 26(3) 247-270, 2006-2007, Baywood Publishing Co., Inc. doi: 10.2190/IQ.26.3.d.

Larno, 2013, http://www.antaranews.com/berita/367 900/menkes-program-kb-gagal.
Lee, Monle \& Johnson, Carla. 1999. Prinsip-Primsip Periklanan dalam Prespektif Global. Jakarta: Prenada Media.

Makalah program keluarga berencana di Indonesia, 2014, http://www.wawasanpendidikan.com/ 2014/08/Makalah-Program-Keluarga-Berencana-di-Indonesia.html.

Mulyana, Dedy. 2005. Ilmu Komunikasi: Sebuah Pengantar. Bandung: Rosdakarya.

Morrisan, M. A. 2010. Periklanan: Komunikasi Pemasaran Terpadu. Jakarta: Kencana Prenada Media Group.

Newland, L., 2010, The deployment of the prosperous family: family planning in West Java, NWSA Journal, 2001: 13, 3.

Setyaningrum, Erna. 2014. Pelayanan Keluarga Berencana dan Kesehatan Reproduksi. Trans Info Media: Jakarta.

Silalahi, Ulber. 2009. Metode Penelitian Sosial. PT. Refika Aditama: Bandung.

Sugiyono. 2011. Metode Penelitian Kuantitatif, Kualitatif, dan $R \& D$. Alfabeta: Bandung.

Shimp, Terence, A. 2000. Periklanan Promosi. Jakarta: Erlangga.

Suhadang, Kustadi. 2010. Periklanan: Manajemen, Kiat, dan Strategi. Bandung: NUASA.

Tylleskär, T., Jackson, D., Meda, N., Engebretsen, I. M. S., Chopra, M., Diallo, A. H., et al. 2011. Exclusive breastfeeding promotion by peer counsellors in sub-Saharan Africa (PROMISE$E B F)$ : a cluster-randomised trial. Lancet, 378, 420-427.

Venus, Antar. 2009. Manajemen Kampanye. Bandung: Simbiosa Rekatama Media. 